\title{
A LATEX BAG TONOMETER FOR DETERMINING THE ANAESTHETIC BLOOD/GAS PARTITION COEFFICIENT
}

\author{
Alfred Feingold, Duncan A. Holaday, and Patrick Walther ${ }^{\circ}$
}

Several methods exist for measuring the relative solubility of anaesthetics in tissues by their tissue/gas partition coefficients. Closed container techniques measure the change in a gas phase equilibrated with the tissue in a closed space. The amount of anaesthetic absorbed by the tissue is calculated from the decreased volume, ${ }^{1}$ pressure ${ }^{2}$ or concentration in the gas phase.:-i; Open container or tonometer techniques measure the concentration of the drug in the tissue phase during equilibration with a continual flow of gas of known concentration." A variant of the tonometer method measures the concentration of drug in the tissue and a reference liquid, usually water. ${ }^{\top}$ The method clescribed in this paper for measuring the blood/gas partition coefficient $(B / G)$ includes features of both open and closed container methods. This method was used to study the effect of in vivo haemodilution on halothane $B / G$.

\section{METHODS}

Latex finger cots $\uparrow$ were filled with $10 \mathrm{ml}$ of blood or water and tied off. This resulted in latex bags filled with water or blood together with a few ml of air. The blood bags were frozen for storige, which haemolyzed the red blood cells.

The bags of water and haemolyzed blood were attached to clamps along the circumference of a multi-specd rotator which rotated at approximately 30 cycles per minute. This was placed inside a constant temperature oven at $37 \pm 1^{\circ} \mathrm{C}$ (Figure 1). Compressed air at $10 \mathrm{l} / \mathrm{min}$ delivered 1 per cent halothane (2-bromo-2 chloro-1,1,1-trifluoroethane) from a Fluotec Mark II vapourizer, through an intake near the oven floor. The gases exhausted through a hole in the top of the oven.

The atmosphere in the oven was analyzed by injecting $0.10 \mathrm{ml}$ samples into a gas chromatograph (Hewlett-Packard 7610A high efficiency gas chromatograph) equipped with $1 / 8^{\prime \prime}$ I.D. $72^{\prime \prime}$ glass column packed with 10 per cent diisodecylphthalate on chromosorb P $60 / 80$ mesh. The chromatograph settings were: oven temperature, $100^{\circ} \mathrm{C}$; injection port temperature, $120^{\circ} \mathrm{C}$; nitrogen flow, $12 \mathrm{ml} / \mathrm{min}$; Hame ionization detector temperature, $160^{\circ} \mathrm{C}$. The peak heights of the sample were compared to peak heights from a 1 per cent halothane gas standard.

The halothane content in water and blood was analyzed as follows: Using a 25-gauge hypodermic needle to pierce the latex bag, $0.5 \mathrm{ml}$ of the liquid was with-

\footnotetext{
*Department of Anesthesiology, University of Miani School of Medicine and Veterans' Administration Hospital, Miami, Florida 33136.

Supported in part by NIH Grant 16498 and a Grant from the Miami Veterans' Administration Hospital.

tClarion Finger Cots, Aloe Medical Corp., St. Louis, Mo.
} 
THERMOMETER

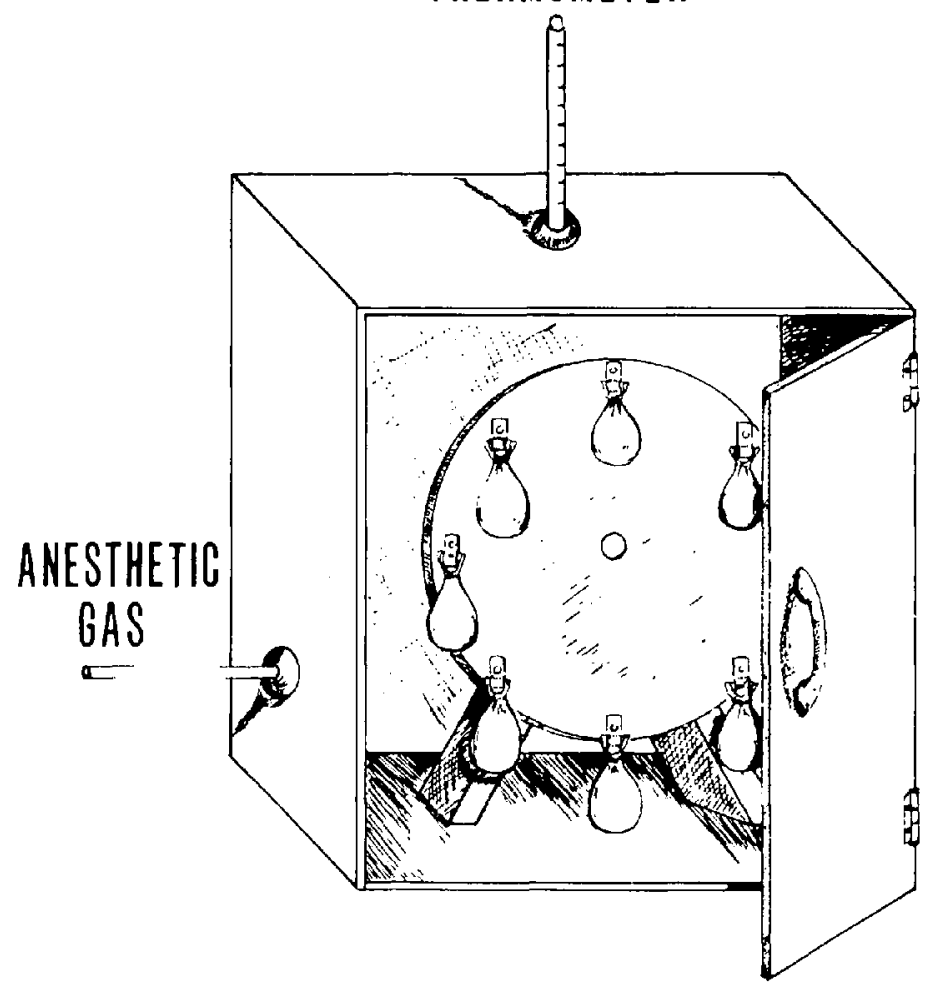

Ficulie 1. Latex bay tonometer appiratus.

drawn into a one $\mathrm{ml}$ ground glass syringe. This was transferred into a $13 \mathrm{ml}$ glass tube with ground glass stopper containing $10 \mathrm{ml}$ of hexane. The liquid and hexane were shaken for five minutes and then analyzed. With a one microliter syringe, $0.4 \mu \mathrm{l}$ of this hexane was injected into the gas chromatograph. This was repeated four times and the mean peak height determined. The hexane analyses were done on $1 / 8^{\prime \prime}$ I.D. $48^{\prime \prime}$ column packed as above. The oven temperature was $80^{\circ} \mathrm{C}$; nitrogen flow $20 \mathrm{ml} / \mathrm{min}$; injection port temperature $120^{\circ} \mathrm{C}$ and the non-pulsed, tritium, electron capture detector temperature at $190^{\circ} \mathrm{C}$. The halothane concentration was calculated by comparing these mean peak heights to laboratory prepared hexane-halothane standards.

The time required for the bags of water and blood to equilibrate with the halothane concentration in the oven was determined by sequential sampling. The water filled bags equilibrated in 45 minutes, the blood filled bags in 100 minutes. An equilibration time of two hours was used for the subsequent analyses. Since the oven door was opened during sampling, the rate of loss of the halothane from the water and blood was also determined by sequential sampling. The water samples did not lose significant anounts of halothane for four minutes, the blood samples for eight minutes. Ten bags could be sampled within this time.

The mean peak height of blood divided by the mean peak height of water gave $B / W . B / G$ was calculated by multiplying $B / W$ by the water/gas coefficient. 


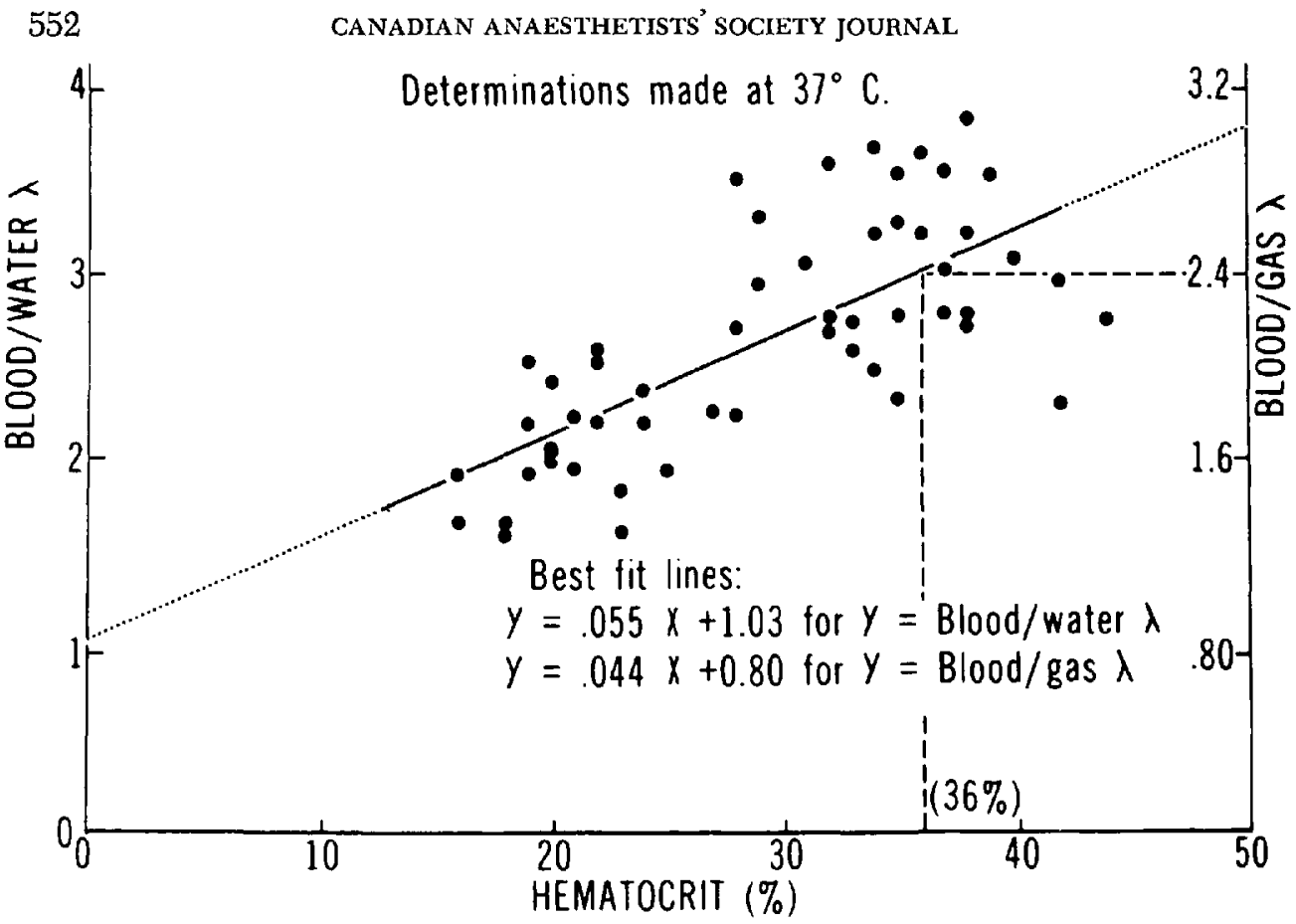

Froune 2. Blood/gas and blood/water partition coefficients $(\lambda)$ in eight patients during hamemodilution.

This technique was used to study the effect of haemodilution on halothane $B / G$ and $\mathrm{B} / \mathrm{W}$ in eight patients undergoing haemodilution with Lactated Ringer's Solution during cardio-pulmonary bypass. Samples of blood were taken throughout the case and analyzed by this method.

The precision of this and previous techniques were evaluated by calculating the coefficient of variation (dividing the standard deviation by the mean and multiplying by 100 ). When the results from several experimental conditions were available, the mean values were used.

\section{Results}

Our experimentally derived water/gas partition coefficient ( $\mathrm{M} \pm \mathrm{SE}$ ) for halothane at $37^{\circ} \mathrm{C}$ was $0.80 \pm 0.01$. The halothane $\mathrm{B} / \mathrm{G}$ at $37^{\circ} \mathrm{C}$ for eight patients prior to haemodilution was $2.48 \pm 0.09$. Both partition coefficients agree with published values. ${ }^{8}$ Halothane $\mathrm{B} / \mathrm{G}$ and $\mathrm{B} / \mathrm{W}$ during and following haemodilution were directly related to the haematocrit of the patient at the time of sampling (Figure 2 ). The least squares best fit line extrapolates to a $B / W$ of 1.03 at zero haematocrit which is not significantly different $(\mathrm{p}<0.01)$ from unity.

The precision of the latex bag technique was evaluated by repeating halothane $B / G$ determinations on the same five blood samples on four consecutive weeks. This resulted in a mean coefficient of variation of 4.5 per cent. In addition, three blood samples were evaluated four times on the same day resulting in a mean coefficient variation of 2.2 per cent. 
Discussion

Most published studies of $B / G$ have used closed container techniques and measured the change in anaesthetic concentration in the gas phase. The volume of blood used for this method has varied between $20 \mathrm{ml}^{-1}$ and $500 \mathrm{ml}^{-1}$ and the volume of the container from $40 \mathrm{ml}^{4}$ to 2 litresi. The mean coefficient of variation for the measurement of the halothane $B / G$ for three studies has been calculated to be 2.7 per cent;" 4.6 per cent, ${ }^{-4}$ and 4.4 per cent. ${ }^{5}$ The precision of the latex bag technique compares favourably with these previously described methods.

One volumetric tochniquen appears useful for clinical studies since it gives $\mathrm{B} / \mathrm{G}$ and anaesthetic blood concentration. However, the precision of this method was not evaluated. One momometric closed container tcchnique ${ }^{2}$ using a specially made pressure chamber appears versatile and has a calculated mean coefficient of variation of 1.7 per cent for the determination of diethyl ether $B / G$. However, only one sample can be run at a time and the chamber is not commercially available.

The conventional open container tonometer appears satisfactory and the calculated mean coefficient of variation for halothane $B / G$ is 4.0 per cent. "However; only one sample can be run at a time and the equilibrating gas may dessicate the sample.

The latex bag technique uses equipment available in most laboratories and allows multiple blood samples to be equilibrated simultaneously. The sample of blood is relatively small and may be stored for later use without transfer. The method requires measurement of anaesthetic concentration in both liquid and gas phases. The water/gas partition coefficient may be determined to any desired accuracy and precision by using large samples. B/W may then be determined using small samples of blood. Sampling errors in the liquid phases then to cancel each other without biasing the results.

Although the latex bag tonometer was used to measure $B / G$, it should be possible to use this method to determine tissue/gas solubilities of anaesthetics in homogenized tissue specimens.

\section{Summary}

Many techniques for measurement of the tissue/gas partition coefficient are valid. Each has specific advantages and shortcomings. All the methods require suitable analytic equipment and means for controlling temperature. The disadvantages of a particular technique, the ability to cope with them and the availability of the necessary apparatus are the determining factors in choosing the best method. The latex bag tonometer has a precision and ease which compares favourably with previously described techniques for measuring anaesthetic blood/gas partition coefficients. The technique was successfully used to show the effect of in vivo haemodilution on the halothane blood/gas partition coefficient.

\section{RÉSUMÉ}

Il existe plusieurs techniques de mesure du "coefficient de partition" tissu/gaz. Chacune présente des avantages et des limitations. Toutes ces méthodes requièrent 
un équipement d'analyse spécifique, et le travail doit être fait à température contrôlée.

Les désavantages d'une méthode, les solutions à ces désavantages et les disponibilités de l'équipement approprié sont des facteurs à considérer dans le choix d'une technique.

Le tonomètre à sac de latex est facile d'usage et donne des résultats comparables à ceux des techniques déjà décrites pour la mesure des coefficients de séparation sang/gaz. La technique a été utilisée avec succès pour démontrer l'effet in vivo de l'hémodilution sur le coefficient de séparation sang/gaz de l'Halothane.

\section{HEFERENCES}

1. Saidian, L.J., Ecien, E.I., Musson, E.S., \& Severinghaus, J.W. Method for determining solubility of anesthetics utilizing the Scholander apparatus. Anesthesiology 27:180-186 (1966).

2. Bachofex, H. \& Farhi, L.E. Simple manometric apparatus for measuring partition coefficients of highly soluble gases. J. Appl. Physiol. 30: 136-139 (1971).

3. Cowles, A.L., Boncstadt, H.H., \& Gillues, A.J. Solubilities of ethylene, cyclopropane, halothanc and diethyl ether in human and dog blood at low concentrations. Anesthesiology 35: 203-211 (1971).

4. Lashere, L.H. \& Hedley-White, I. Halothane solubility in blood and solutions of plasmal proteins effect of temperature, protein composition and hemoglobin concentration. Anesthesiology 32: 351-356 (1970).

5. Lansox, C.P., Erien, E.I. II, \& SEvennghaus, J.W. The solubility of halothane in blood and tissut homogenates. Anesthesiology 23: 349-355 (1962).

6. IKIDA, S. Determination of the solubility of halothane in canine blood and cerebral tissues at hypothermia, using a tonometer for constant gas flow equilibration. Anesthesiology 37: $87-91(1972)$.

7. Low', II.J. Determination of volatile organic anesthestics in gases, blood and tissues. Gas Chromatography, Crune \& Stratton, Inc, New York, pp. 19t-209 (1968).

8. Steward, A., Allót, P.R., Cowles, A.L., \& Mapleson, W.W. Solubility coefficients for inhaled anesthetics for water, oil and biological media. Brit. J. Anaesth. 45: 282-293 (1.973).

9. Fisk, B.R. \& Momikawa, K. A simplified method for the measumement of volatile anesthetics in blood by gas chromatography. Anesthesiol, 32: 451-455 (1970). 